\title{
PENDIDIKAN ISLAM DI KERAJAAN TURKI USMANI
}

\author{
Sulaiman Saat \\ UIN Alauddin Makassar, Jl. Sultan Alauddin No. 63 Makassar \\ E-mail: sulaiman_saat@ymail.com
}

\begin{abstract}
Abstrak: Kerajaan Turki Usmani merupakan salah satu kerajaan Islam yang cukup berpengaruh di daratan Eropa pada sekitar abad ke-13 hinga ke-20 M. Dalam masa pemerintahannya, Turki Usmani tidak banyak memperhatikan dunia pendidikan. Jika dibandingkan dengan masalah politik, pendidikan pada masa pemerintaham Turki Usmani jauh tertinggal. Selama berkuasa kurang lebih tujuh abad, Turki Usmani tidak banyak melahirkan ilmuan yang berpengaruh dalam dunia Islam. Lemahnya di bidang pendidikan dan perluasan wilyah yang tidak terkendali, pemberontakan wilayah-wilayah, rusaknya moral penguasa, korupsi yang meraja lela, menyebabkan Turki Usmani tidak dapat bertahan ketika Barat datang menggempur dengan persenjataan modern hasil rekayasa melalui pendidikan mereka.

Abstract: The kingdom of the Ottoman Turk was one of the Islamic kingdoms very influential in Europe lands in around the thirteenth century until the fifteenth century A.D. During its rule, the Ottoman Turk had no great concern to the development of education compared with political sector. Consequently, the Islamic education during the rule of the kingdom left behind. For about seven centuries of its rule, the Ottoman Turk produced no influential scientist in Islamic word. The backwardness in the field of education and the expansion as well as the corruption of the ruler's morality brought about the disability of the kingdom to oppose the Western attack with modern arm forces as the result of their technological engineering.
\end{abstract}

Kata Kunci: pendidikan Islam, Kerajaan Turki Usmani 


\section{PENDAHULUAN}

Dalam sejarah, umat Islam telah mengalami perjalanan panjang yang pasang surut. Setelah masa khulafaurrasyidin, dimana kekuasaan di bidang pemerintahan telah berada dalam dua kekhalifahan, yakni Dinasti Bani Umayyah dan Dinasti Bani Abbasiah. Sejarah telah mencatat, bahwa kedua dinasti tersebut, telah mencatat sejarah yang gemilang di muka bumi. Daulat Bani Umayyah telah mendirikan imperium belahan barat yang berpusat di Spanyol dan Andalusia sebagai pusat pemerintahan, dan dinasti Bani Abbasiah menjadi penguasa di belahan Timur, dengan Bagdad sebagai pusat pemerintahan dan kebudayaan. Setelah kedua dinasti tersebut hancur, sejarah peradaban Islam dilanjutkan oleh kerajaan-kerajaan Islam lainya, walaupun tidak sebesar dengan kedua dinasti terdahulu.

Satu di antara sejarah peradaban Islam yang cukup menarik untuk bahan kajian ilmiah, yaitu masa abad pertengahan, khususnya pada abad ke-17 karena pada masa itu terdapat tiga kerajaan besar, yaitu Kerajaan Syafawi di Persia, Kerajaan Mughal di India, dan kerajaan Utsmani di Turki. ${ }^{1}$ Munculnya kerajaankerajaan Islam di abad pertengahan, menunjukkan bahwa kekuatan Islam belum berakhir, walaupun kedua dinasti terdahulu, Umayyah dan Abbasiah, telah hancur.

Pada tulisan ini, penulis membatasi diri dengan hanya memusatkan perhatian pada perkembangan pendidikan di masa Turki Usamani. Hal ini menjadi menarik untuk dianalisis, karena kerajaan Turki Usmani telah mengukir sejarah yang panjang dalam sejarah Islam secara keseluruhan. Panulis berkeinginan untuk melihat sisi-sisi dari kerajaan Turki Usmani, yang menyebabkan bangkitnya kerajaan ini ditengah-tengah kehancuran kerajaan Islam lainnya. Kerajaan Turki Usmani merupakan salah satu kerajaan Islam yang paling besar serta

${ }^{1}$ Dedi Supriadi, Sejarah Peradaban Islam (cet. ke-1; Bandung: Pustaka Setia, 2008), h. 248. 
paling lama berkuasa. Pada masa Sultan Usman, orang Turki telah menguasai daerah yang sangat luas,antara Kaukasus dan kota Wina, menguasai daerah-daerah sekitar laut tengah dan berabadabad lamanya Turki merupakan faktor penting dalam perhitungan ahli-ahli politik di Eropa Barat. ${ }^{2}$ Kerajaan Usmani (Ottoman) berkuasa secara meluas di Asia Kecil sejak munculnya pembina dinasti ini pada tahun 1305 M. Lahirnya kerajaan Turki Usmani telah mengembalikan nama besar kekuasaan Islam. Raksasa baru ini mengangkang di Bosporus, satu kakinya di Asia dan kaki lainnya di Eropa. Dia telah mewarisi kekuasaan Bizantium, dan juga mewarisi kekhalifahan di Arab. Pewarisan tanah dari Timur dan Barat ini diimbangi dengan pewarisan berbagai pemikiran, dan gabungan dari berbagai peninggalan itu bisa jadi merupakan fakta yang paling nyata dalam sejarah Turki Usmani. Tulisan ini akan mengkaji perkembangan pendidikan Islam pada masa kekuasaan Kerajaan Turki Usmani.

\section{SEJARAH KERAJAAN TURKI USMANI}

Dari berbagai literatur yang membicarakan tentang asal usul Kerajaan Turki Usmani dapat dipahami, bahwa Kerajaan Turki Usmani didirikan oleh bangsa Turki dari kabilah Orhuz yang mendiami daerah Mongol dan daerah Utara negeri Cina. ${ }^{3}$ Bangsa Turki berasal dari keluarga Qabey, sebuah kabilah yang memiliki karakteristik sebagai al-Ghazw al-Turkī, yaitu bangsa Badui yang suka berperang. Cikal bakal lahirnya dinasti Usmaniah bermula dari kafilah yang dipimpin Arthogrol. ${ }^{4}$ Menurut Hamka dalam Supriadi, kerajaan Turki Usmani dibangsakan kepada nenek moyang mereka yang pertama, Sultan Usmani Ibnu Sauji

\footnotetext{
${ }^{2}$ Samsu Munir Amin, Sejarah Peradaban Islam (cet. ke-1; Jakarta: Amzah, 2009), h. 194. Bandingkan dengan Ibid., h. 248.

${ }^{3}$ Abuddin Nata, Sejarah Pendidikan Islam (cet. ke-2; Jakarta: PT. Raja Grapindo Persada, 2010), h. 272.

${ }^{4}$ Samsul Nizar, Sejarah Pendidikan Islam Menelusuri Jejak Pendidikan Era Rasulullah sampai Indonesia (cet. ke-3; Jakarta: Kencana Prenada Media Group, 2007), h. 197.
} 
Ibnu Orthogol Ibnu Sulaiman Syah Ibnu Kia Alp, kepala Kabilah Kab di Asia Tengah. Turki Usmani berkuasa sejak abad ke-13 sampai abad ke-19. Raja pertama Turki Usmani adalah Utsman dengan gelar Padisyah Ālu Ușmān atau raja dari keluarga Utsman. $^{5}$ Padisyah Ālu Ușmān (Usman I) mengumumkan berdirinya kerajaan Turki Usmani pada tahun 699 H/1300 M. ${ }^{6}$ Pendiri kerajaan ini dan keturunannya berkuasa sampai tahun 1922 M. ${ }^{7}$ Ini menunjukkan bahwa kerajaan ini mulai berkuasa dari abad ke-14 sampai dengan awal abad ke-20. Suatu masa kekuasaan yang sangat panjang, sekitar 7 abad lamanya, dan diperintah oleh 36 orang raja, sejak diproklamirkannya oleh Usman pada tahun 1299 M. dan menjadi raja pertama sampai dengan Muhammad IV Wahīd al-Dīn sebagai raja terakhir yang memerintah tahun 19181922 M. $^{8}$ Kerajaan Turki Usmani mencapai puncaknya pada masa pemerintahan Sultan Muhammad II (1451-1484 M). Usaha ini dilanjutkan oleh raja-raja sesudahnya, hingga dikembangkan oleh Sultan Sulaimān al-Qānūn (1520-1566 M). Kerajaan Turki Usmani diperintah oleh raja-raja yang memiliki keahlian di bidang politik pemerintahan, dan kemiliteran, sehingga tidak heran jika kerajaan ini dapat menguasai daerah yang sangat luas, yang meliputi semenanjung Balkan, Asia Kecil, Arab Timur Tengah, Mesir, Afrika Utara. ${ }^{9}$

Sebuah kerajaan, akan selalu mengalami masa gemilang dan masa suram, seperti halnya dengan kerajaan Turki Usmani. Masa gemilang di alami ketika kerajaan ini diperintah oleh raja-raja yang memiliki kemampuan pengelola pemerintahan dengan baik, mengatur pertahanan dan keamanan negara, memiliki kekuatan

${ }^{5}$ Supriadi, Sejarah Peradaban ..., h. 248.

${ }^{6}$ Badri Yatim, Sejarah Peradaban Islam (Jakarta: PT. Raja Grapindo Persada, 1993), h. 130.

${ }^{7}$ Ibid., h. 194.

${ }^{8}$ Philip K. Hitti, History of the Arabs, terj. R. Cecep Lukman Yasin dan Dedi Slamet Riadi dan Qomaruddin SF, (cet. ke-1; Jakarta: PT. Serambi Ilmu Semesta, 2008), h. 905-910.

${ }^{9}$ Supriadi, Sejarah Peradaban ..., h. 48. 
militer yang cukup tangguh. Di antara hal-hal yang mendukung tegaknya pemerintahan kerajaan Turki Usamni adalah tata pemerintahan dan militer yang sangat baik, kemajuan di bidang ilmu pengetahuan dan budaya, walaupun di bidang ilmu pengetahuan Turki Usmani tidak terlalu menonjol, tetapi di bidang budaya, Turki Usmani mengadakan akulturasi budaya antara Arab, Persia, dan Bizantium, sehingga kerajaan ini memiliki suatu kebudayaan yag sangat kompleks. Selain itu kemajuan di bidang pertahanan dan kemeliteran sangat pesat. Namun setelah masa gemilang lewat, masa suram menghantui kerajaan ini, keruntuhan kerajaanpun tidak dapat dielakkan.

Runtuhnya Kerajaan Turki Usmani pasca Sultan Sulaiman, diakibatkan karena perebutan kekuasaan antara putra-putranya sendiri. Para pengganti Sultan Sulaiman, sebagian orang-orang yang lemah dan mempunyai sifat dan keperibadian yang buruk. Juga karena lemahnya semangat perjuangan prajurit Usmani yang mengakibatkan kekalahan dalam menghadapi beberapa peperangan, ekonomi semakin memburuk, sifat pemerintahan tidak berjalan semestinya. Penguasa Turki Usmani hanya mengadakan ekspansi, perluasan wilayah, tanpa memperhitungkan penataan sistem pemerintahan. Hal ini menyebabkan wilayah-wilayah yang jauh dari pusat pemerintahan direbut oleh musuh dan sebagian berusaha melapaskan diri. Selain itu, juga disebabkan oleh wilayah kekuasaan yang sangat luas, sehingga pemerintah kesulitan menjalankan administrasi pemerintahan. Faktor lain adalah, kelemahan para penguasa, munculnya budaya pungli, pemberontakan tentara Jenisari, merosotnya ekonomi, dan terjadinya stagnasi dalam bidang ilmu pengetahuan dan teknologi. ${ }^{10}$

\footnotetext{
${ }^{10}$ Dyah Ratna Met Novia, Kerajaan Turki Usmani, www.kerajaanturki Usmani/co.id, diakses 22 Februari 2011
} 
Uraiann di atas menunjukkan bahwa kemajuan dan kemunduran suatu bangsa, tidak terlepas dari watak para penguasanya. Kerajaan Turki Usmani mengalami kemajuan di saat penguasanya adalah orang-orang yang memiliki komitmen memajukan bangsanya, sehingga selain mengadakan perluasan wilayah kekuasaan, juga tidak melupakan penataan dalam negeri yang telah dikuasainya. Memperbaiki administrasi pengelolaan negara, kemajuan pertahanan dan militer, kemajuan di bidang ilmu pengatahuan dan kebudayaan sebagai syarat untuk mengisi pembangunan bangsa, kehidupan bidang keagamaan yang dapat membentengi negara dari hal-hal yang bersifat amoral, merupakan persyaratan bagi tegaknya sebuh negara. Sebaliknya, sebuah negara dengan wilayah yang sangat luas, heterogenitas penduduk, kelemahan penguasa, akhlak pejabat yang rusak, dan terjadinya stagnasi dalam bidang ilmu pengetahuan dan teknologi, merupakan bayangan akan kehancuran sebuah pemerintahan, dan ini pula yang dialami oleh Kerajaan Turki Usmani.

H.D. Sirojuddin AR. Mengemukakan beberapa faktor yang menyebabkan kemunduran kerajaan Turki Usmani, yang meliputi: perluasan wilayah, administrasi yang tidak beres, bangsa dan agama yang heterogen, kebobrokan Konstantinopel, penghianatan para putri istana, pemebrontakan zukisyariah, budaya pungli meraja lela, dekadensi moral, perang yang berkesinambungan, mengabaikan kesejahteraan rakyat, dan munculnya gerakan rasionalisme. ${ }^{11}$

Kenyataan-kenyataan seperti itu telah menjadi momok bagi setiap kekuasaan. Titik lemah suatu negara atau kekuasaan, jika dalam negara atau kekuasaan tersebut telah tumbuh sifat-sifat yang demikian. Sifat rakus kekuasaan wilayah tanpa ada pengaturan yang baik, penghianatan internal, moral tidak

${ }^{11}$ H.D. Sirojuddin, Sejarah Kebudayaan Islam I (Jakarta: Dirjen Bimbaga Islam, 1995/1996), h. 332-333. 
menjadi ukuran dalam pengambilan keputusan, para penguasa berpoya-poya dengan uang rakyat dan mengabaikan kesejahteraan rakyat, membuat rakyat semakin tidak berdaya, padahal rakyat adalah tulang punggung suatu negara. Inilah yang titik kelemahan Kerajaan Turki Usmani.

\section{PERKEMBANGAN PENDIDIKAN ISLAM PADA MASA KERAJAAN TURKI USMANI}

Sesuai dengan karakter dan sejarah bangsa Turki Usmani yang berasal dari keluarga Qabey, sebuah kabilah yang memiliki karakteristik sebagai al-Ghazw al-Turkī yaitu bangsa Badui yang suka berperang. Ibnu Khaldum dalam Robert $H$. Lauer menggambarkan kehidupan orang Badui bahwa orang Badui tidak mampu mendapatkan selain dari pemenuhan kebutuhan hidup yang paling sederhana saja. Cara hidup inilah yang menimbulkan dari diri mereka keberanian yang besar dan tingkat menentukan nasib sendiri yang sangat tinggi. Kerasnya kehidupan di padang pasir, memerlukan usaha kerjasama yang timbul dari solidaritas kelompok. Akibat semua ini, adalah menjadikan orang Badui "sebagai manusia terganas yang pernah ada". ${ }^{12}$

Seperti telah disinggung pada uraian terdahulu, bahwa masyarakat Turki Usmani merupakan masyarakat yang memiliki keahlian di bidang perang. Tidak heran jika yang menjadi perhatian utamanya adalah kemajuan di bidang militer dan pertahanan. Kamajuan ilmu pengetahuan berada jauh di bawah kemajuan di bidang militer. Pada etape kedua abad pertama di bawah pimpinan Sultan Sulaimān I (diangkat tahun $1520 \mathrm{M}$ ), wilayah kekuasaan Turki telah sampai di semenanjung Balkan. Pasukan Turki yang secara etnografis dan geneologis memiliki

\footnotetext{
${ }^{12}$ Robert H. Lauer, Perspektif tentang Perubahan Sosial (cet. ke-2; Jakarta: Rineka Cipta, 1993), h. 44.
} 
katangguhan dalam perang, terus melakukan ekspansi dan penyebaran Islam. ${ }^{13}$

Dalam pembahasan perkembangan pendidikan di masa Kerajaan Turki Usmani, Abuddin Nata membaginya dalam dua periode, yakni zaman pertengahan dan zaman modern.

Perkembangan Pendidikan Zaman Pertengahan (Usman I, $1300 \mathrm{M}$. sampai Pra Mahmud II, 1808 M.)

Perkembangan pendidikan Islam pada Kerajaan Turki Usmani tidak terlepas setting budaya, dan kondisi sosial politik. Kebudayaan Turki merupakan perpaduan antara kebudayaan Persia, Byzantium dan Arab. Kebudayaan Persia, telah banyak menanamkan ajaran-ajaran tentang etika dan tatakrama dalam kehidupan istana. Masalah organisasi, pemerintahan, dan kemiliteran, mereka dapatkan dari kerajaan Byzantium, sedangkan dari kebudayaan Arab, mereka mendapatkan ajaran tentang ekonomi, kemasyarakatan dan ilmu pengetahuan. ${ }^{14}$

Perkembangan ilmu pengetahuan dan kebudayaan tidak banyak mengalami kemajuan di badingkan dengan kekuaan militer, kecuali pada beberapa aspek, seperti kehidupan keagamaan. Ulama (muftī), menduduki jabatan penting dalam negara dan masyarakat. Mufti sebagai pejabat tinggi agama berwewenang menyampaikan fatwa resmi mengenai problematika keagamaan. Kegiatan tarekat juga berkembang pesat, seperti tarekat al-Bektasyi yang sangat berpengaruh di kalangan tentara Yennissery, dan tarekat Maulawy berpengaruh besar di kalangan penguasa. Sufisme pada waktu itu digemari umat Islam dan berkembang pesat. Keadaan frustrasi yang merata di kalangan umat karena hancurnya tatanan intelektual dan material akibat konflik internal dan serangan tentara Mongol, menyebakn orang kembali kepada Tuhan dan bersikap fatalistik.

${ }^{13}$ Nata, Sejarah Pendidikan ..., h. 281.

${ }^{14}$ Binnaz Toprak, Islam and Political Development in Turkey (Leiden: E. J. Brill, 1981), h. 60. Lihat pula Nata, ibid., h. 283. 
Madarasah-madrasah berkembang menjadi zawiyah-zawiyah untuk mengadakan riyādah, merintis jalan untuk kembali kepada Tuhan di bawah bimbingan guru-guru sufi. Ilmu pengetahuan keislaman, seperti fikih, tafsir, ilmu kalam dan lain-lain, tidak mengalami perkembangan. Kebanyakan penguasa Usmani cenderung bersikap taklid dan fanatisme terhadap suatu mazhab dan menentang mazhab yang lain. ${ }^{15}$

Tentang perkembangan sufi, Fazlurrahman dalam Abuddin Nata melukiskan masa itu sebagai berikut:

\begin{abstract}
Sebagian besar pusat-pusat sufi terutama di Turki, kurikulum akademis terdiri hampir seluruhnya buku-buku tentang sufi. Di Turki waktu itu terdapat beberapa tempat khusus Methanevikhana, dimana Matsnawinya merupakan satu-satunya buku yang diajarkan. Lebih jauh lagi, isi dan karya-karya tersebut yang sebagian besar dikuasai pantheisme adalah bertentangan secara tajam dengan lembaga-lembaga pendidikan ortodoks. Karena itu timbullah dualisme spritual yang tajam dan berlarut-larut antara madrasah dan halaqah. Ciri khas dari fenomena ini adalah melimpahnya pertanyaan-pertanyaan sufi yang taubat setelah menemukan jalan, lalu membakar buku-buku madrasah mereka atau melemparkannya ke dalam sumur. ${ }^{16}$
\end{abstract}

Melihat kondisi yang dialami oleh penguasa Turki Usmani, karena latar belakang mereka adalah bangsa yang suka berperang, ekspansi dan perluasan wilayah menjadi fokus perhatian, sedangkan bidang pendidikan dan kebudayaan tertinggal jauh, kurang mendapatkan perhatian. Akibatnya, ketika Barat mulai bangkit di bidang militer, para penguasa Turki Usmani tidak berdaya menghadapi gempuran Barat. Persenjataan yang mereka miliki tidak semoderen yang dimiliki oleh Barat sebagai hasil dari kemajuan teknologi yang sudah mereka persiapkan. Sejarah membuktikan bahwa suatu negara atau bangsa yang tidak menghiraukan pendidikan, lama kelamaan akan ketinggalan dan ditinggalkan oleh kemajuan teknologi.

${ }^{15}$ Yatim, Sejarah Peradaban ..., h. 137.

${ }^{16} \mathrm{Ibid}$., 285. 


\section{Zaman Modern (Mahmud II, 1808-1922 M.)}

Mahmud II (Sultan ke-33) dinilai sebagai sebagai penggagas repormasi Usmani, khususnya perubahan di bidang pendidikan. Ia ingin merubah pola madrasah tradisional disesuaikan dengan zamannya (abad ke-19) dan mengikis buta aksara. Dalam kurikulum baru dimasukkan mata pelajaran umum. Ia mulai mendirikan madrasah pengetahuan umum serta sastera, Mekteb-i Ma'ārif dan Mekteb-i 'Ulūm-u Adabiye. Siswa kedua sekolah itu dipilih dari madrasah yang bermutu tinggi. Di kedua madrsah itu diajarkan bahasa Perancis, ilmu bumi, sejarah, dan ilmu politik, di samping bahasa Arab. Setelah itu Sultan Mahmud II mendirikan pula sekolah militer, sekolah teknik, sekolah kedokteran dan sekolah pembedahan. Sekolah kedokteran dan pembedahan digabung dalam satu wadah Dār-ul lum-u Hikamiye ve Mekteb-i Tibbye-i Sahane menggunakan bahasa Prancis. Di sinilah mulai muncul ide-ide modern sebagai counter opinion atas pahampaham fatalistik yang telah lama menyelimuti masyarakat. ${ }^{17}$

Dengan demikian, memasuki periode abad ke-19 dan ke-20, Kerajaan Turki Usmani telah mengadakan repormasi di bidang pendidikan. Kalau selama ini mereka terkungkung dengan sikap fatalisme dan fanatisme, maka Sultan Mahmud II telah membuat gerakan repormasi yang sangat besar di bidang pemikiran (pendidikan). Sultan Mahmud II mulai menyadari bahwa penyebab kakacauan dan kemunduran pemerintahan, salah satu penyebabnya adalah karena sikap patalisme yang mereka pegang. Kemandegan ilmu pengetahuan dan teknologi Kerajaan Usmani ada kaitannya dengan perkembangan metode berpikir yang kolot dan tradisional, dan di kalangan ulama mereka cenderung menutup diri dari pengaruh kamajuan Eropa, dan ini dikaitkan dengan menurunnya semangat berpikir bebas akibat pemahaman tasawuf. ${ }^{18}$

\footnotetext{
${ }^{17}$ Ibid., h. 286-287.

${ }^{18}$ Supriyadi, Sejarah Peradaban ..., h. 252.
} 
Walaupun Kerajaan Usmani cenderung tertutup karena tradisi tasawuf yang mereka pegang teguh, namun harus diakui pula bahwa Kerajaan Usmani telah mencatat berbagai kemajuan di bidang ilmu pengetahuan (pendidikan). Perkembangan etnik Turki di kawasan ini dalam tradisi sastra atau budaya cukup kaya dan mengesankan. Periode Islam merupakan periode yang paling panjang dan sangat menentukan untuk melihat potensi dasar intelektual dan spritual Turki yang dipadukan dengan kekuatan Persia-Irano yakni antara abad ke-9 sampai paro abad ke-19. Diawali oleh imam besar ahli hadis al-Bukhārī (w.870 M). Intelektual Islam pertama yang berasal dan telah bercokol di wilayah ini merupakan warisan utama dan kebanggaan tersendiri. Perkembangan berikutnya, intelektual, sastra, dan budaya mereka kembangkan di bawah para amīr. ${ }^{19}$ Dalam bidang sastra, prosa Kerajaan Usmani melahirkan dua tokoh terkemuka, yaitu Katip Celebi dan Elviya Celebi. Katip Celebi yang lebih dikenal dengan Mustafa Abdullah seorang penulis terbesar. Karya terbesarnya adalah Kasyf al-Zunūn fĩ Asmāì al-Kutub wa al-Funūn, sebuah presentasi biografi penulis-penulis penting di dunia timur bersama daftar dan deskripsi lebih dari 1.500 buah buku berbahasa Turki, Persia, dan Arab. ${ }^{20}$

Dari beberapa bidang yang tampak dalam peradaban Turki Usmani, seperti pemerintahan dan militer, bidang ilmu pengetahuan, bidang kebudayaan, dan bidang keagamaan, bidang pemerintahan dan militer merupakan yang paling banyak mendapatkan perhatian dan kemajuan, karena dilatarbelakangi oleh watak dan karakter orang Turki (Badui). Sementara itu, bidang pendidikan dan ilmu pengetahuan yang paling kurang mendapatkan perhatian. Itulah sebabnya, dalam khasanah intelektual Islam, tidak ditemukan ilmuan terkemuka dari Turki Usmani. Demikian juga dalam bidang keagamaan, selain tasawuf,

\footnotetext{
${ }^{19}$ Ajid Thohir, Studi Kawasan Dunia Islam Perspektif Etno-Linguistik dan Geo-Politik, ed. I (Jakarta: Raja Grapindo Persada, 2009), h. 246.

${ }^{20}$ Amin, Sejarah Peradaban Islam..., h. 203.
} 
ilmu-ilmu keagamaan seperti fikih, tafsir, ilmu kalam, dan hadis, boleh dikatakan tidak mengalami perkembangan yang berarti. Namun demikian, jika dilihat dari sisi perkembangan kebudayaan material (fisik), Kerajaan Turki Usmani mengalami perkembangan yang sangat maju. Hal ini terutama dapat dilihat pada karya seperti arsitektur masjid, istana, kuburan, permandian umum, rumah sakit, sekolah, dan tata kota. Pada bidang-bidang ini, Turki Usmani menunjukkan karya yang bernilai arsitektur yang sangat tinggi. ${ }^{21}$

Dalam kaitannya dengan pendirian lembaga pendidikan (madrasah), di masa Turki Usmani, merupakan kelanjutan keberadaan mdrassah tradisional yang ada sebelumnya. Bedanya adalah madrasah yang dibangun pada masa Turki Usmani telah lebih maju karena telah memiliki kurikulum sendiri. Tidak hanya di Istambul, saat itu, madrasah juga didirikan di Edirne, Beograd, dan Sofia. Madrasah ketika itu seakan menjadi penjaga kesetaraan. Saat itu, madrasah memberikan kesempatan yang sama kepada semua individu untuk mendapatkan akses pendidikan. Madrasah juga didirikan dengan tujuan menjadi bagian integral dari kehidupan sosial, terutama untuk memenuhi kebutuhan intelektual masyarakat. Madrasah sebagai pusat pendidikan dan kesetaraan terus menyebar seiring dengan kian luasnya kekuasaan Turki Usmani. Saat menaklukkan sebuah wilayah baru, segera dibangun mesjid dan madrasah. Secara struktural, madrasash-madrasash itu merupakan bagian dari sistem wakaf dan otonomi secara finansial. Kegiatan madrasah di bawah pengawasan negara.

Pada periode sebelum berkuasanya Sultan Mahmud II, pendidikan di madrasah ditekankan pada studi agama. Namun demikian, selanjutnya madrasah juga memasukkan bahan ajaran lainnya. Kemudian muncul daftar pelajaran seperti ilmu logika, filsafat, dan matematika, mulai diajarkan oleh para guru di

\footnotetext{
${ }^{21}$ Nizar, Sejarah Pendidikan Islam ..., h. 200-205.
} 
berbagai madrasah. Di madrasah tertentu juga diajarkan ilmu kedokteran dan astronomi. Ini mendorong pendirian rumah sakit dan obsevatorium. Selama abad ke-19, masih terdapat 166 madrasah yang aktif di Istambul dengan 5.369 murid. Namun demikian, pada tahun 1924, setelah berdirinya Republik Turki, setelah revolusi pendidikan, madrasah Kekaisaran Turki Usmani dihapuskan fungsinya. ${ }^{22}$ Dengan demikian, madrasah sebagai lembaga pendidikan sudah kehilangan tempat dalam pemerintahan Republik Turki.

Jadi dapat disimpulkan bahwa pendidikan pada masa Kerajaan Turki Usmani kurang mendapatkan perhatian, dibandingkan dengan kekuatan politik kekuasaan. Satu-satunya yang banyak mendapatkan perrhatian adalah kemajuan di bidang sufi, tetapi itupun hanya dijadikan sebagai kompensasi bagi para penguasa Turki Usmani untuk sekedar keluar dari kerumitan permasalahan kenegaraan yang tidak dapat diselesaikan.

\section{PENUTUP}

Berdasarkan uraian yang telah dikemukakan, dapat ditarik kesimpulan bahwa Kerajaan Usmani merupakan suatu kekuatan baru setelah runtuhnya dua dinasi Islam, Umayyah dan Abbasiyah, yang telah mengukir sejarah panjang kekuasaan Islam. Kelanggengan Kerajaan Turki Usmani didukung oleh penguasa yang memiliki kemampuan, khususnya di bidang politik pemerintahan. Setelah berkuasa sekitar tujuh abad dengan daerah kekuasaan yang sangat luas, dipimpin oleh 36 orang raja, akhirnya kerajaan ini runtuh. Keruntuhan itu diakibatkan, selain faktor eksternal, yang paling mempengaruhi keruntuhan itu adalah faktor internal Kerajaan Turki Usmani sendiri.

${ }^{22} \mathrm{http} /$ www.republika.co.id/berita/ensiklopedia-islam/khazanah/10/04 /16/ 111 464-lihatlah-potret-madrasah-di-era-turki-usmani, diakses 22 Februari 2011 
Perkembangan pendidikan pada masa Turki Usmani tidak terlalu menonjol, kecuali dalam beberapa bidang, seperti seni arsitektur. Hal ini disebabkan karena perhatian para penguasa Kerajaan Turki Usmani tidak pada bidang pendidikan, melainkan pada bidang militer dan pemerintahan.

\section{DAFTAR PUSTAKA}

Hitti, Philip K. History of The Arabs, terj. Cecep Lukman Yasin dan Dedi Slamet Riadi dan Qomaruddin SF, cet. ke-1; Jakarta: PT. Serambi Ilmu Semesta, 2008.

http/www.republika.co.id/berita/ensiklopedia-islam/khazanah/10/04/ 16/111 464-lihatlah-potret-madrasah-di-era-turki-usmani, diakses 22 Februari 2011

Munir Amin, Samsu. Sejarah Peradaban Islam, cet. ke-1, Jakarta: Amzah, 2009.

Nata, Abuddin, Sejarah Pendidikan Islam, cet. ke-2; Jakarta: PT. Raja Grapindo Persada, 2010.

Novia, Dyah Ratna Met, Kerajaan Turki Usmani, www.kerajaanturki usmani/co.id, diakses 22 Februari 2011

Nizar, Samsul, Sejarah Pendidikan Islam Menelusuri Jejak Pendidikan Era Rasulullah sampai Indonesia, cet. ke-3; Jakarta: Kencana Prenada Media Group, 2007.

Robert H. Lauer, Perspektif tentang Perubahan Sosial, cet. ke-2; Jakarta: Rineka Cipta, 1993.

Sirojuddin, H.D., Sejarah Kebudayaan Islam I, Jakarta: Dirjen Bimbaga Islam, 1995/1996.

Supriadi, Dedi, Sejarah Peradaban Islam. cet. ke-1; Bandung: Pustaka Setia, 2008.

Thohir, Ajid, Studi Kawasan Dunia Islam Perspektif Etno-Linguistik dan Geo-Politik. ed. I, Jakarta: Raja Grapindo Persada, 2009.

Toprak, Binnaz, Islam and Political Development in Turkey, Leiden, E. J. Brill, 1981.

Yatim, Badri, Sejarah Peradaban Islam, Jakarta: PT. Raja Grapindo Persada, 1993. 